PLAN OF STUDY TO DETERMINE THE EFFECT OF CHANGES IN HERBICIDE USE ON HERBICIDE CONCENTRATIONS IN MIDWESTERN STREAMS, 1989-94

U.S. GEOLOGICAL SURVEY

Open-File Report 94-347

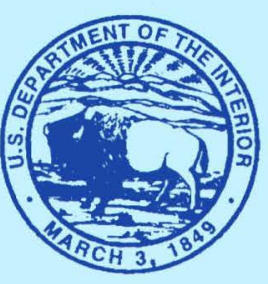




\section{PLAN OF STUDY TO DETERMINE THE EFFECT OF CHANGES IN HERBICIDE USE ON HERBICIDE CONCENTRATIONS IN MIDWESTERN STREAMS, 1989-94}

By Donald A. Goolsby, Laurie L. Boyer, and William A. Battaglin

\section{U.S. GEOLOGICAL SURVEY}

Open-File Report 94-347

Denver, Colorado

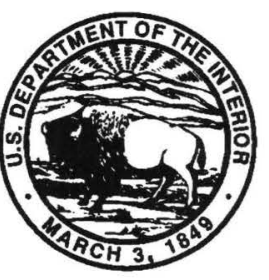




\section{U.S. DEPARTMENT OF THE INTERIOR \\ BRUCE BABBITT, Secretary \\ U.S. GEOLOGICAL SURVEY \\ Gordon P. Eaton, Director}

Use of trade names in this report is for identification purposes only and does not constitute endorsement by the U.S. Geological Survey

For additional information write to:

Regional Hydrologist

U.S. Geological Survey

Box 25046, Mail Stop 406

Federal Center

Denver, CO 80225-0046
Copies of this report can be purchased from:

U.S. Geological Survey

Books and Open-File Reports Section

Box 25425, Mail Stop 517

Federal Center

Denver, CO 80225-0425 


\section{CONTENTS}

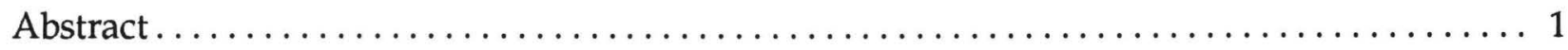

Introduction $\ldots \ldots \ldots \ldots \ldots \ldots \ldots \ldots \ldots \ldots \ldots \ldots \ldots \ldots \ldots \ldots \ldots \ldots \ldots \ldots \ldots$

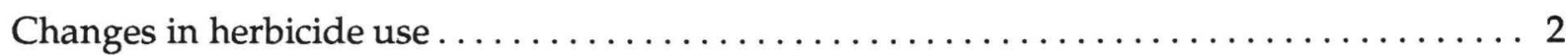

Nitrate in area affected by 1993 flood. . . . . . . . . . . . . . 5

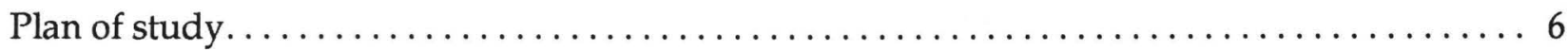

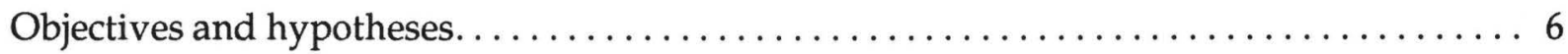

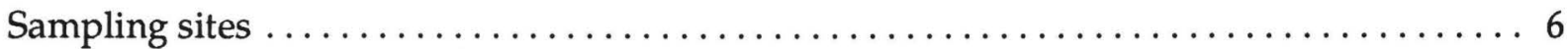

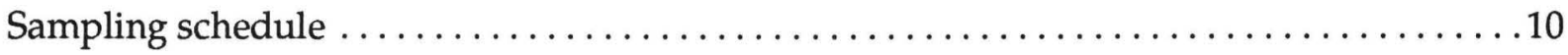

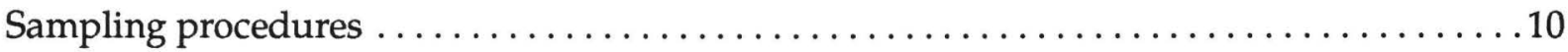

Analytical procedures. . . . . . . . . . . . . . . . 10

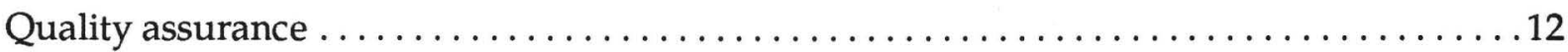

Data analysis methods and reports. . . . . . . . . . . . . . . . 12

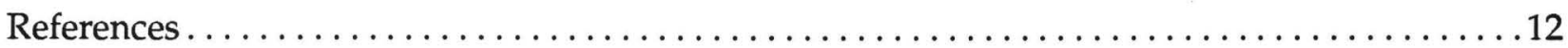

\section{FIGURES}

1. Boxplots showing the seasonal distribution in concentrations of selected herbicides detected during three sampling periods in $1991 \ldots \ldots \ldots \ldots \ldots \ldots \ldots \ldots \ldots$

2. Boxplots showing the distribution in concentrations of selected herbicides at approximately 50 sites sampled in both 1989 and 1990 during pre- and post-application

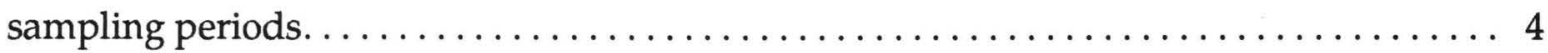

3. Map showing the location of drainage basins and sites to be sampled for herbicides and

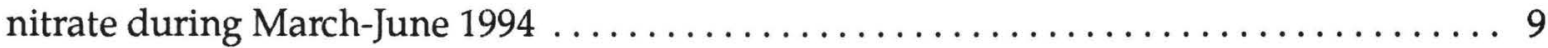

\section{TABLES}

1. Sites to be sampled during March-June 1994 to investigate the effects of changes in herbicide use on herbicide concentrations in streams $\ldots \ldots \ldots \ldots \ldots \ldots \ldots \ldots$

2. Physical properties and chemical compounds to be determined for samples collected

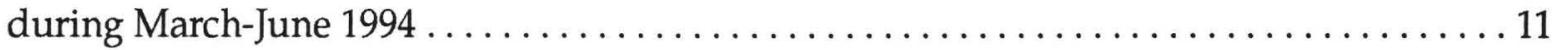




\section{CONVERSION FACTORS AND ABBREVIATED WATER-QUALITY UNITS}

\section{Multiply}

cubic foot per second $\left(\mathrm{ft}^{3} / \mathrm{s}\right)$ pound

square mile $\left(\mathrm{mi}^{2}\right)$

acre

cubic foot $\left(\mathrm{ft}^{3}\right)$
By

$2.832 \times 10^{-2}$

$4.536 \times 10^{-1}$

2.590

$4.047 \times 10^{3}$

$4.047 \times 10^{-1}$

$4.047 \times 10^{-3}$

$2.447 \times 10^{3}$
To obtain

cubic meter per second

kilogram

square kilometer square meter $\left(\mathrm{m}^{2}\right)$

square hectometer $\left(\mathrm{hm}^{2}\right)$

square kilometer $\left(\mathrm{km}^{2}\right)$

cubic meter $\left(\mathrm{m}^{3}\right)$

Temperature can be converted from degrees Celsius $\left({ }^{\circ} \mathrm{C}\right)$ to Fahrenheit $\left({ }^{\circ} \mathrm{F}\right)$ by using the following equation:

$$
{ }^{\circ} \mathrm{F}=9 / 5\left({ }^{\circ} \mathrm{C}\right)+32 .
$$

\section{Abbreviated Water-Quality Units}

microgram per liter $(\mu \mathrm{g} / \mathrm{L})$

microsiemens per centimeter at 25 degrees Celsius $(\mu \mathrm{S} / \mathrm{cm})$

milligram (mg)

milligram per liter $(\mathrm{mg} / \mathrm{L})$

milliliter (ml) 


\title{
PLAN OF STUDY TO DETERMINE THE EFFECT OF CHANGES IN HERBICIDE USE ON HERBICIDE CONCENTRATIONS IN MIDWESTERN STREAMS, 1989-94
}

\author{
By Donald A. Goolsby, Laurie L. Boyer, and William A. Battaglin
}

\begin{abstract}
An approach was developed to determine if recent changes in the use of herbicides has affected herbicide concentrations in Midwestern streams. This approach also provides a plan to determine if the abnormally high rainfall and flooding in 1993 has an effect on nitrate concentrations in 1994 in streams that flooded in 1993. The approach involves sampling 53 stream sites, 50 of which were sampled in 1989 and 1990 as part of a reconnaissance to determine the geographic and seasonal distribution of herbicides in 10 Midwestern States. Sites will be sampled twice, once prior to application of herbicides, in March or early April, and once during the first runoff event after application of herbicides. Samples will be analyzed for 11 herbicide and 2 atrazine metabolites by gas chromatography/mass spectrometry. Samples will also be analyzed for ESA (an alachlor metabolite), two cyanazine metabolites, and nutrients.

Changes to the manufacturers' label have decreased the maximum recommended application rate for atrazine on corn and sorghum by about 50 percent since the 1989-90 study. Conversely, the use of other herbicides, such as cyanazine, has increased by more than 25 percent since 1989. Statistical procedures such as Wilcoxon signed rank tests for paired samples will be used to determine if the distributions of herbicide and nitrate concentrations in 1994 are different from those measured in 1989 and 1990.
\end{abstract}

\section{INTRODUCTION}

In 1989 the U.S. Geological Survey (USGS) Toxic Substances Hydrology Program conducted a reconnaissance of about 150 streams in 10 Midwestern States to determine the geographic and seasonal distribution of herbicides. These streams were sampled three times: (1) before application, (2) during the first major runoff event after application, and (3) during low flow in the fall. Results from the study showed that large amounts of atrazine, cyanazine, alachlor, and metolachlor were flushed into streams during the first post-application runoff event (Thurman and others, 1991, 1992; Goolsby and Battaglin, 1993). Both atrazine and cyanazine temporarily exceeded health-based limits in about one-half of the streams. The atrazine maximum contaminant level (MCL) is $3 \mu \mathrm{g} / \mathrm{L}$ (micrograms per liter); the cyanazine health advisory (HA) is $1 \mu \mathrm{g} / \mathrm{L}$. In addition, alachlor temporarily exceeded the alachlor MCL of $2 \mu \mathrm{g} / \mathrm{L}$ in about 35 percent of the streams. Although the concentrations of some herbicides exceeded MCLs in some of the post-application samples, this does not necessarily constitute a violation of the Safe Drinking Water Act (SDWA). A violation occurs only if the average annual concentration exceeds the MCL or if the herbicide concentration in a single sample is more than four times the MCL. Thus, samples with atrazine concentrations exceeding $12 \mu \mathrm{g} / \mathrm{L}$ or alachlor concentrations exceeding $8 \mu \mathrm{g} / \mathrm{L}$ may represent violations of the SDWA if the water is used for public supply. About 25 percent of the samples collected during the post-application period had atrazine concentrations larger than four times the MCL and about 15 percent had alachlor concentrations larger than four times the MCL (fig. 1). Cyanazine has a nonenforceable HA of $1 \mu \mathrm{g} / \mathrm{L}$; the 
cyanazine concentration in about 25 percent of the post -application samples exceeded four times the HA (fig. 1). The maximum concentration of several herbicides exceeded $50 \mu \mathrm{g} / \mathrm{L}$ (fig. 1). Herbicide concentrations were much lower (generally less than $1 \mu \mathrm{g} / \mathrm{L}$ ) during the preapplication and fall low-flow sampling periods; however, more than one-half the streams had detectable concentrations in all three sampling periods.

The 1989 reconnaissance documented for the first time the seasonal and geographic distribution of herbicides in streams at a regional scale. Because of the high post-application concentrations measured, and because of an increased level of concern caused by the results, a follow-up study was conducted in 1990 to verify the 1989 results. In the verification study 50 sites were selected for resampling. Selection of the sites was accomplished by ranking all samples from the 1989 post-application sampling round from highest to lowest according to the total herbicide concentration. This concentration is defined as the sum of the concentrations of all herbicides measured in each sample. These sites were then divided into three equal groups. From the group containing the highest concentrations, 25 sites were randomly selected. Similarly, 13 sites were randomly selected from the middle group, and 12 sites were randomly selected from the low concentration group. These sites were resampled before application and during the first runoff event after application in 1990 using the same protocols developed for the 1989 study. Results from the 1990 study confirmed the 1989 results. The statistical distributions of the concentrations of the major herbicides detected in these 50 streams were essentially the same during the pre- and post-application periods of both years (Goolsby and others 1991; also see figure 2). These results and those of other studies (Baker and Richards, 1989; Frank and others 1982; Leonard, 1988; Snow and Spalding, 1988; and Wauchope, 1978) further indicated that the "flush" of herbicides following application is an annual occurrence. Additional studies by the USGS in 1990 and 1991 using automatic samplers (Thurman and others 1992; Goolsby and Battaglin, 1993) show that the herbicide "flush" lasts for several weeks to several months following application. By late summer, herbicide concentrations generally decrease to low concentrations (less than $0.5 \mu \mathrm{g} / \mathrm{L}$ ) and remain low until the process is repeated the following year.

\section{Changes in Herbicide Use}

Since the 1989-90 regional-scale studies were conducted, two reductions have occurred in the maximum application rate of atrazine recommended by the manufacturers' label. In 1990, because of concern about ground-water contamination, the manufacturers of atrazine voluntarily reduced the maximum recommended application rate for atrazine to 3 pounds a.i. (active ingredient) per acre per year for corn and sorghum (U.S. Environmental Protection Agency (EPA), written commun., Jan. 23, 1990). Prior to this, the recommended maximum application rate was 4 pounds a.i. per acre per year. The 1990 label change also restricted noncropland uses of atrazine to 10 pounds a.i. per year. This label change applied to all products released for shipment after September 1, 1990.

In 1992, due in part to concern about surface-water contamination, the manufacturers of atrazine further voluntarily reduced the maximum recommended application rate of atrazine to a range of 1.6 to 2.5 pounds a.i. per acre per year depending on soil organic residue and erosion potential. The maximum amount recommended per application is 2 pounds a.i. per acre. Up to 0.5 pound a.i. per acre per year can be applied in subsequent applications (EPA, written commun., March 8, 1993). The total of all applications cannot exceed 2.5 pounds a.i. per acre per year. 

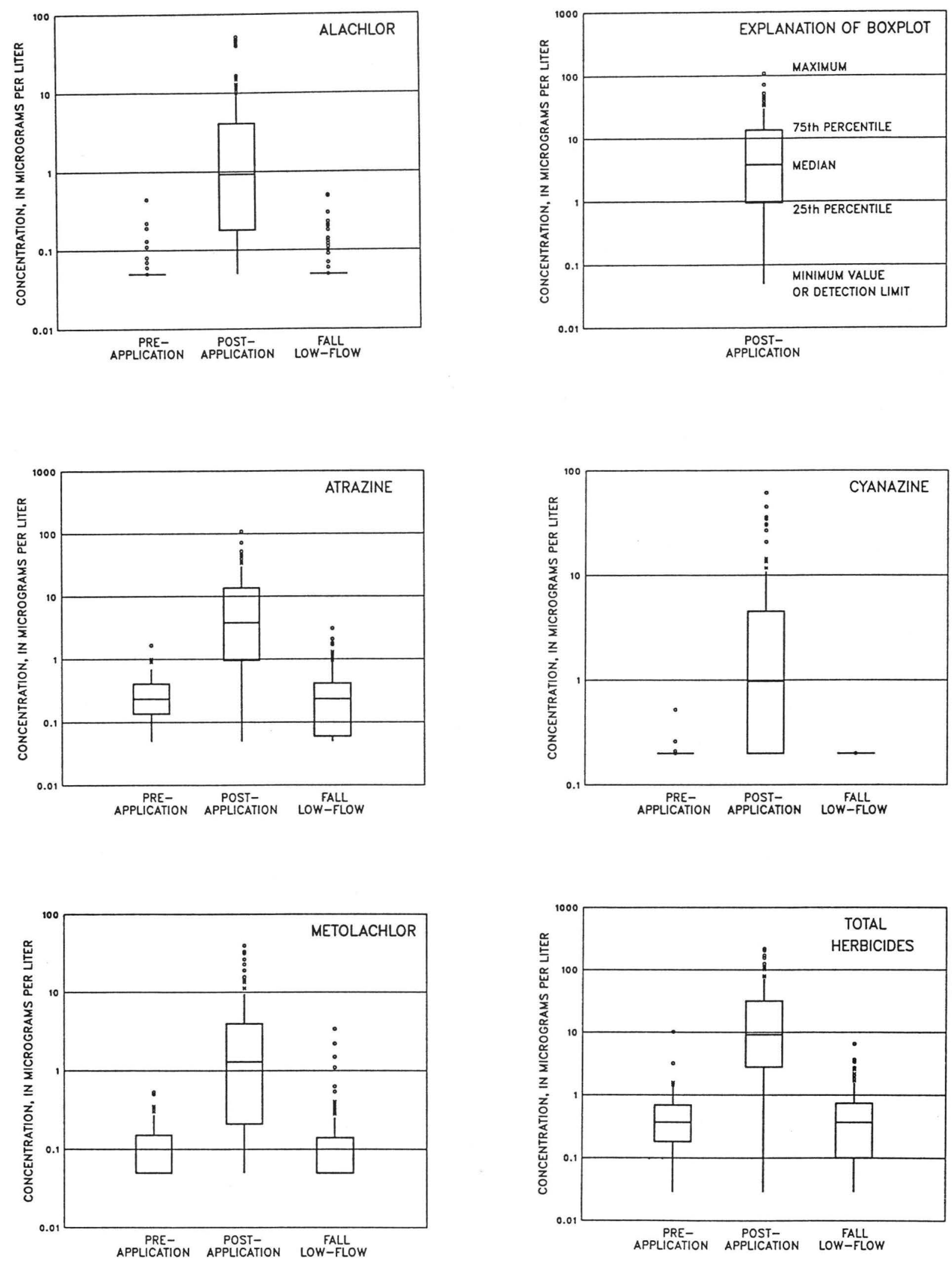

Figure 1. The seasonal distribution in concentrations of selected herbicides detected during three sampling periods in 1989. 

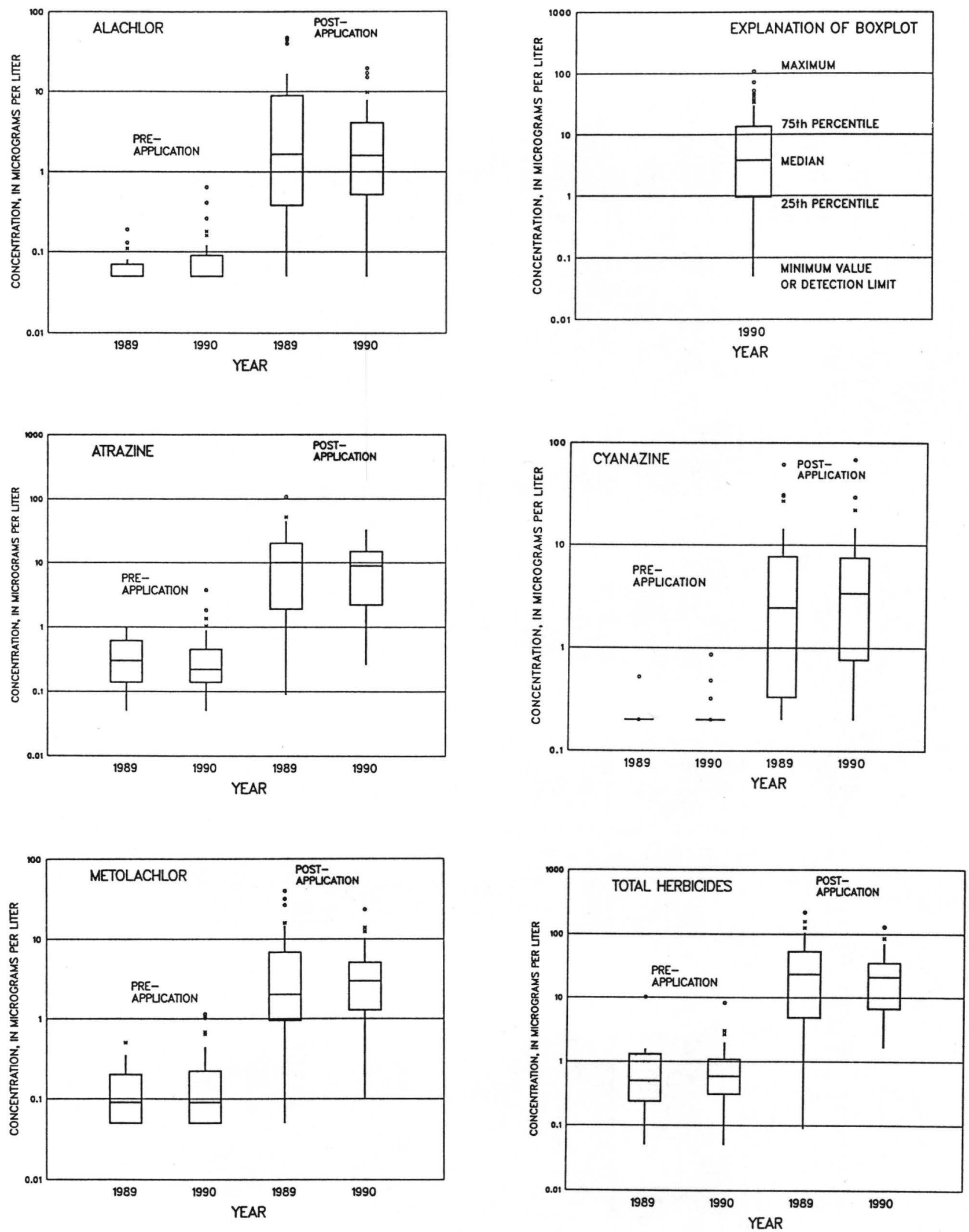

Figure 2. The distribution in concentrations of selected herbicides at approximately 50 sites sampled in both 1989 and 1990 during pre- and post-application sampling periods. 
A maximum of 1.6 pounds a.i. per acre per year is recommended on soil with less than 30 percent plant residue remaining on the surface. Most non-cropland uses of atrazine are no longer recommended under the label. This label change was effective with all products shipped for use after August 1, 1992.

As a result of these two voluntary label changes, the maximum application rate for atrazine on corn and sorghum has essentially been reduced by 50 percent since the 1989-90 studies were conducted. However, no information is available to determine if atrazine was always applied at the maximum recommended rate. There is reason to believe, however, that there has been a substantial reduction in the per acre application rate of atrazine since the 1989-90 regional studies of atrazine in streams. Further, assuming there has been no substantial increase in the acres planted in corn and sorghum in the 1989-94 time period, there should have been a substantial overall reduction in the use of atrazine. This could be reflected in an overall reduction in atrazine concentrations in Midwestern streams. The 50 sites sampled in 1989 and 1990 provide a good data set from which to determine if there has been a measurable decrease in atrazine concentrations.

Conversely, the use of other herbicides, such as cyanazine has increased since 1989. According to data from the U.S. Department of Agriculture (USDA), the estimated use of cyanazine on corn and sorghum increased from 20.7 million pounds a.i. per year in 1989 to 26.7 million pounds a.i. per year in 1992 (Gianessi, 1992; USDA, 1990, 1991, 1992), an increase of more than 25 percent. Data from these sources also indicate that the use of metolachlor has increased since 1989. The 1989-90 data set would also provide a baseline from which to determine if the concentrations of these herbicides in Midwestern streams have changed.

\section{Nitrate in Area Affected by 1993 Flood}

The Mississippi - Missouri River flood of 1993 occurred throughout the western one-half of the area encompassed by the 1989-90 herbicide studies. It is unlikely that the 1993 flood will have any affect on concentrations of herbicides in the flood-affected streams in 1994, because herbicides are transported to streams primarily by overland runoff during a 1 to 2 month period following application rather than by ground-water baseflow. However, the 1993 flood may have an effect on nitrate concentrations in some Midwestern streams in 1994. In a study of the Raccoon River in Iowa, Lucey and Goolsby (1993) showed that during years of below-normal precipitation there appeared to be an accumulation of nitrate in the soil and unsaturated zone, and during subsequent years of above-normal precipitation some of this stored nitrate was leached into streams. This resulted in low nitrate concentrations in the Raccoon River during dry years and high concentrations during wet years. Similar observations have been made in other studies of nitrate in Midwestern streams and the Mississippi River (Goolsby and Battaglin, 1993; Goolsby and others, 1993). In most of the streams studied, nitrate concentrations increased as streamflow increased during winter and spring. Also, the highest nitrate concentrations in the Mississippi River during 1991-93 were measured during periods when streamflow was high. These results suggest that stream basins affected by abnormally high rainfall in 1993 could have higher concentrations of nitrate in 1994 than in 1989-90 if soil moisture content remains high and streamflow is above-normal. If streamflows in the spring and summer of 1994 are similar to or lower than in 1989-90, nitrate concentrations could be similar to those measured during the 198990 studies. A comparison of nitrate data collected in 1994 with data from these same streams in 1989-90 would provide a basis for determining if this is indeed true. The 1993 flood probably flushed a considerable amount of nitrate out of the soil, unsaturated zone, and ground water, but 
because of the high annual use of nitrogen fertilizer in the Midwest (more than 6 million metric tons per year; Battaglin and others, 1993), a large reservoir of nitrate probably remains in the hydrologic system.

\section{PLAN OF STUDY}

The following material is a plan for a study to determine if changes in herbicide usage since 1990 have resulted in changes in herbicide concentrations in Midwestern streams. The proposed study also provides a plan to determine if the abnormally high rainfall and flooding in 1993 had an effect on nitrate concentrations in 1994 in the streams that flooded in 1993. In addition, the proposed study will provide an opportunity to further examine the distribution of the alachlor soil metabolite ESA (alachlor ethane sulfonic acid) and the cyanazine metabolites deethylcyanazine and cyanazine amide. ESA is one of the most abundant herbicide compounds found in Midwestern reservoirs and shows relatively little seasonal variation (Goolsby, Battaglin, Fallon, and others, 1993). These results suggest that ESA is very persistent and is transported in a manner more similar to nitrate than to the other herbicide compounds being studied. Analyses for deethylcyanazine and cyanazine amide in sample extracts from the 1989-90 studies indicate that the abundance and distribution of these compounds is similar to cyanazine (Mike Meyer, USGS, Lawrence, Kansas, unpublished data, 1994).

\section{Objectives and Hypotheses}

The principal objective of the proposed study is to determine if changes in the application rate recommended by the manufacturers of atrazine have resulted in an overall reduction in atrazine concentrations in Midwestern streams since 1990. Secondary objectives are to: (1) determine if overall changes since 1990 in the concentrations of cyanazine, metolachlor, and nitrate can be detected in these streams, (2) determine the seasonal and geographic distribution of the alachlor soil metabolite ESA, and (3) compare the seasonal and geographic distribution of the cyanazine metabolites cyanazine amide and deethylcyanazine with 1990 results. Specific hypotheses to be tested are:

1. The overall concentrations of atrazine and desethylatrazine in Midwestern streams during runoff following application will be lower in 1994 than in 1989 and 1990.

2. The concentrations of cyanazine, cyanazine amide, and deethylcyanazine during runoff following application will be higher in 1994 than in 1990.

3. ESA will be detected at a frequency and in concentrations similar to that of atrazine.

4. ESA will show much less seasonal variation (pre-application compared to post-application) in concentrations than the other herbicides and metabolites studied.

5 Nitrate concentrations in the stream basins affected by the 1993 flood will be higher in 1994 than in 1989 and 1990.

\section{Sampling Sites}

Fifty three (53) stream sites will be sampled in this study. Of these, 50 will be the same sites sampled for the 1990 study. These sites were selected from the 1989 reconnaissance as described 
earlier in this workplan. Three additional sites to be sampled are those where automatic samplers were operated in 1990 to determine the temporal distribution of herbicides in several Midwestern streams. The location of the sites to be sampled and their drainage basins are shown in figure 3 .

Sampling sites, drainage areas, 1990 sampling dates, and 1990 streamflows are given in table 1.

Table 1.--Sites to be sampled during March-June 1994 to investigate the effects of changes in herbicide use on herbicide concentrations in streams

$\left[\mathrm{mi}^{2}\right.$, square miles; $\mathrm{ft}^{3} / \mathrm{s}$, cubic feet per second; --, no data]

\begin{tabular}{|c|c|c|c|c|c|c|c|}
\hline \multirow[b]{2}{*}{$\begin{array}{c}\text { Map } \\
\text { no. }\end{array}$} & \multirow[b]{2}{*}{ State } & \multirow[b]{2}{*}{$\begin{array}{c}\text { Site } \\
\text { number }\end{array}$} & \multirow[b]{2}{*}{ Site name } & \multirow[b]{2}{*}{$\begin{array}{c}\text { Drainage } \\
\text { area } \\
\left(\mathrm{mi}^{2}\right)\end{array}$} & \multicolumn{2}{|c|}{ Sampling dates } & 1990 \\
\hline & & & & & $\begin{array}{c}\text { Pre- } \\
\text { planting }\end{array}$ & $\begin{array}{c}\text { Post- } \\
\text { planting }\end{array}$ & $\begin{array}{c}\text { planting } \\
\text { streamflow } \\
\left(\mathrm{ft}^{3} / \mathrm{s}\right)\end{array}$ \\
\hline
\end{tabular}

1 Iowa 05411600 Turkey River at Spillville

2 Iowa 05421000

3 Iowa 05455100

4 Iowa 05472500

5 Iowa 05474000

6 Iowa 05480500

7 Iowa 05484500

8 Iowa 06606600

9 Iowa 06607200

10 Iowa 06609500

11

12

13

14

15

16

17

18

19

20

21

22

23

24

25

26

27

28

29

30

31

32

33

34

Wapsipinicon River at Independence

Old Mans Creek near Iowa City

N. Skunk River near Sigourney

Skunk River at Augusta

Des Moines River at Fort Dodge

Raccoon River at Van Meter

Little Sioux River at Correctionville

Maple River at Mapleton

Boyer River at Logan

Bonpas Creek at Browns

Little Wabash at Carmi

South Branch Kishwaukee, Fairdale

Iroquois River near Chebanse

Dupage River near Shorwood

Spoon River at London Mills

Sangamon River at Riverton

Macoupin Creek near Kane

Kaskaskia near Cowden

Shoal Creek near Breese

III. 05592100

05594000

Ind. $\quad 03275000$

Ind. 03302800

Ind. 03328500

Ind. 03333450

Ind. 03335000

Ind. 03351000

Ind. 03362500

Ind. 03371500

Kans.

06885500

Whitewater River near Alpine

Blue River at Fredricksburg

Eel River near Logansport

Wildcat Creek near Jerome

Wildcat Creek near Lafayette

White River near Nora

Sugar Creek near Edinburgh

E. Fork White River near Bedford

Black Vermillion River near Frankfort

Kans. 06890100

Delaware River near Muscotah

Cottonwood River near New Ulm

Minn. 05476000

Des Moines River at Jackson

Minn. 06483000

Rock River at Luverne

Mo. $06817700 \quad$ Nodaway River near Graham
1770

1048

201

730

4303

4190

3441

2500

669

871

228

3088

387

2091

324

1072

2618

868

1330

735

522

283

789

146

794

1219

474

3861

410

431

1280

1220

425

1320
$03 / 22 / 90 \quad 06 / 14 / 90$

$03 / 22 / 90 \quad 05 / 09 / 90$

$03 / 15 / 90 \quad 05 / 04 / 90$

$03 / 15 / 90 \quad 05 / 21 / 90$

$03 / 08 / 90 \quad 06 / 21 / 90$

$03 / 16 / 90 \quad 06 / 15 / 90$

$05 / 03 / 90 \quad 05 / 10 / 90$

$03 / 16 / 90 \quad 06 / 14 / 90$

$03 / 16 / 90 \quad 06 / 13 / 90$

$03 / 16 / 90$

$06 / 13 / 90$

$04 / 17 / 90 \quad 07 / 10 / 90$

$04 / 17 / 90 \quad 07 / 10 / 90$

$04 / 12 / 90 \quad 05 / 14 / 90$

$04 / 04 / 90 \quad 05 / 17 / 90$

$04 / 04 / 90 \quad 06 / 22 / 90$

$04 / 10 / 90 \quad 05 / 14 / 90$

$03 / 26 / 90 \quad 05 / 14 / 90$

$03 / 28 / 90 \quad 05 / 14 / 90$

$03 / 27 / 90 \quad 05 / 14 / 90$

$03 / 28 / 90$

$05 / 04 / 90$

$03 / 27 / 90$

$05 / 15 / 90$

$03 / 27 / 90$

$05 / 15 / 90$

$03 / 26 / 90$

$05 / 14 / 90$

$03 / 26 / 90 \quad 05 / 14 / 90$

$03 / 26 / 90 \quad 05 / 14 / 90$

$03 / 26 / 90$

$03 / 27 / 90$

$05 / 14 / 90$

05/15/90

$03 / 27 / 90$

$05 / 15 / 90$

$03 / 22 / 90$

$05 / 16 / 90$

$04 / 04 / 90$

05/09/90

$05 / 01 / 90 \quad 06 / 05 / 90$

$05 / 08 / 90 \quad 06 / 19 / 90$

$05 / 08 / 90 \quad 06 / 19 / 90$

424

212

$04 / 10 / 90 \quad 05 / 22 / 90$

612 
Table 1.--Sites to be sampled during March-June 1994 to investigate the effects of changes in herbicide use on herbicide concentrations in streams

$\left[\mathrm{mi}^{2}\right.$, square miles; $\mathrm{ft}^{3} / \mathrm{s}$, cubic feet per second]

\begin{tabular}{|c|c|c|c|c|c|c|c|}
\hline \multirow[b]{2}{*}{$\begin{array}{l}\text { Map } \\
\text { No. }\end{array}$} & \multirow[b]{2}{*}{ State } & \multirow[b]{2}{*}{$\begin{array}{l}\text { Site } \\
\text { number }\end{array}$} & \multirow[b]{2}{*}{ Site Name } & \multirow[b]{2}{*}{$\begin{array}{l}\text { Drainage } \\
\text { area } \\
\left(\mathrm{mi}^{2}\right)\end{array}$} & \multicolumn{2}{|c|}{ Sampling dates } & \multirow{2}{*}{$\begin{array}{c}1990 \\
\text { post- } \\
\text { planting } \\
\text { streamflow } \\
\left(\mathrm{ft}^{3} / \mathrm{s}\right)\end{array}$} \\
\hline & & & & & $\begin{array}{l}\text { Pre- } \\
\text { planting }\end{array}$ & $\begin{array}{c}\text { Post- } \\
\text { planting } \mathrm{s}\end{array}$ & \\
\hline 35 & Nebr. & 06803000 & Salt Creek at Roca & 167 & $03 / 27 / 90$ & $06 / 07 / 90$ & 59 \\
\hline 36 & Nebr. & 06804000 & Wahoo Creek at Itica & 271 & $03 / 20 / 90$ & $06 / 08 / 90$ & 126 \\
\hline 37 & Nebr. & 06880800 & W. Fork Big Blue River-Dorchester & 1206 & $04 / 03 / 90$ & $05 / 10 / 90$ & 130 \\
\hline 38 & Nebr. & 06815000 & Big Nemaha at Fall City & 1340 & $03 / 27 / 90$ & $05 / 17 / 90$ & 1447 \\
\hline 39 & Nebr. & 06882000 & Big Blue River at Barn & 4447 & $03 / 21 / 90$ & $05 / 17 / 90$ & 801 \\
\hline 40 & Nebr. & 06884000 & Little Blue River near Fairbury & 2350 & $03 / 21 / 90$ & $05 / 17 / 90$ & 258 \\
\hline 41 & Ohio & 03157000 & Clear Creek near Rockbridge & 89 & $03 / 22 / 90$ & $05 / 26 / 90$ & 1250 \\
\hline 42 & Ohio & 03219500 & Scioto River near Prospect & 567 & $03 / 23 / 90$ & $05 / 15 / 90$ & 2540 \\
\hline 43 & Ohio & 03223000 & Olentangy River at Claridon & 157 & $03 / 21 / 90$ & $05 / 14 / 90$ & 1380 \\
\hline 44 & Ohio & 03230500 & Big Darby Creek at Darbyville & 534 & $03 / 22 / 90$ & $05 / 15 / 90$ & 3090 \\
\hline 45 & Ohio & 03234500 & Scioto River at Higby & 5131 & $03 / 26 / 90$ & $05 / 15 / 90$ & 15400 \\
\hline 46 & Ohio & 03240000 & L. Miami River near Oldtown & 129 & $03 / 22 / 90$ & $05 / 14 / 90$ & 608 \\
\hline 47 & Ohio & 03267900 & Mad River at Eagle City & 310 & $03 / 22 / 90$ & $05 / 14 / 90$ & 1100 \\
\hline 48 & Ohio & 04185000 & Tiffin River at Stryker & 410 & $03 / 21 / 90$ & $05 / 14 / 90$ & 966 \\
\hline 49 & Ohio & 04186500 & Auglaize River near Fort Jennings & 332 & $03 / 21 / 90$ & $05 / 14 / 90$ & 2100 \\
\hline 50 & Wis. & 04087240 & Root River at Racine & 190 & $03 / 27 / 90$ & $07 / 19 / 90$ & 31 \\
\hline 51 & Wis. & 05340500 & St. Croix River at St. Croix Falls & 6240 & $04 / 23 / 90$ & $07 / 30 / 90$ & 5600 \\
\hline 52 & Wis. & 05407000 & Wisconsin River at Muscoda & 10400 & $03 / 20 / 90$ & $06 / 22 / 90$ & 15400 \\
\hline 53 & Wis. & 05430500 & Rock River at Afton & 3340 & $04 / 12 / 90$ & $07 / 06 / 90$ & 2540 \\
\hline
\end{tabular}




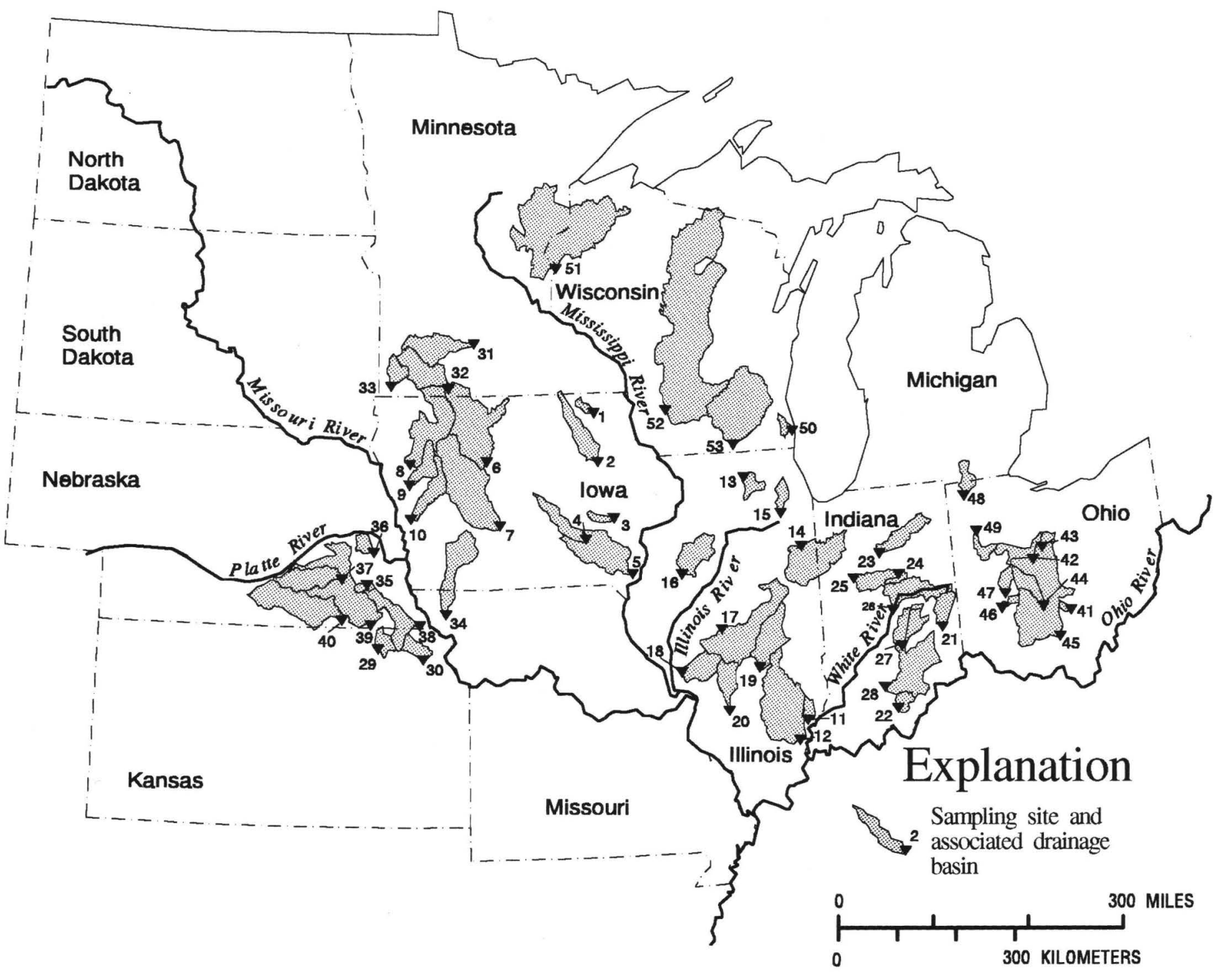

Figure 3. The location of drainage basins and sites to be sampled for herbicides and nitrate during March-June 1994. 


\section{Sampling Schedule}

The first sample (pre-application) will be collected at each site prior to the application of herbicides in March or early April. To the extent possible, this sample will be collected when some overland runoff is occurring to help determine the extent to which herbicides are carried over from previous application periods.

A second (post-application) sample will be collected at each site after herbicides have been applied and following the first precipitation event that produces overland flow. Collection of this sample will require a special visit to the site. To the extent possible, this sample will be collected near the discharge recorded when the 1990 sample was collected. Attempts were made in 1990 to collect the sample near the peak discharge for the event. Results and hydrographs from the 1989 sampling and studies using autosamplers in 1990 show that this is when the largest concentrations occur.

\section{Sampling Procedures}

Samples will be collected with a depth integrating sampler from three or more verticals. Sufficient volume of water will be collected in glass, Teflon, or stainless-steel sampling bottles (for example, sediment bottles) to make field measurements of $\mathrm{pH}$ and specific conductance (unless these are measured in situ). Samples from the three or more verticals will be composited in a 1liter or larger glass, Teflon, or stainless-steel container. All sampling equipment will be cleaned with non-phosphate detergent, rinsed thoroughly with tap water, then distilled/deionized water, followed by a final rinse with a 50-percent solution of methanol and organic-free water. Samples will be filtered through glass fiber filters for herbicide analysis, and through membrane filters for nitrogen and phosphorus analysis.

Four 125-ml glass bottles from each site will be sent to the USGS laboratory in Lawrence, Kansas, for the analysis of herbicide compounds, and a $125 \mathrm{ml}$ polyethylene bottle will be sent to the USGS National Water Quality Laboratory in Denver for analysis of dissolved nitrogen and phosphorus compounds. Field measurements for specific conductance, $\mathrm{pH}$, and temperature will be taken for all samples and a discharge will be obtained by direct measurement, from a rating curve, or estimated from a nearby gaging station.

\section{Analytical Procedures}

All samples will be analyzed for 11 herbicides and 2 atrazine metabolites (table 2) by gas chromatography/mass spectrometry according to procedures described by Thurman and others (1990) and Meyer and others (1993). ESA will be analyzed by the method of Aga and others (1994) and cyanazine metabolites will be analyzed by a method developed by M.T. Meyer (unpublished). Nitrogen and phosphorus compounds (table 2) will be analyzed by the method described by Fishman and Friedman (1989). 
Table 2.--Physical properties and chemical compounds to be determined for samples collected during March-June 1994

$\left[\mathrm{ft}^{3} / \mathrm{s}\right.$, cubic feet per second; $\mu \mathrm{S} / \mathrm{cm}$, microsiemens per centimeter at 25 degrees Celsius;

${ }^{\circ} \mathrm{C}$, degrees Celsius; $\mathrm{mg} / \mathrm{L}$, milligrams per liter; $\mu \mathrm{g} / \mathrm{L}$, micrograms per liter; $\mathrm{N}$, nitrogen;

$\mathrm{P}$, phosphorus; SPE, solid phase extraction; GC/MS, gas chromatography/mass spectrometry; ELISA, enzyme-linked immunosorbent assay]

\begin{tabular}{llc}
\hline Property or compound & Method & Reporting limit \\
\hline streamflow & meter or rating & $0.01 \mathrm{ft}^{3} / \mathrm{s}$ \\
specific conductance & meter & $1 \mu \mathrm{S} / \mathrm{cm}$ \\
$\mathrm{pH}$ & electrometric & $0.1 \mathrm{unit}$ \\
temperature & thermometer or & $0.1^{\circ} \mathrm{C}$ \\
& thermister &
\end{tabular}

\section{Nutrients}

nitrite as $\mathrm{N}$

nitrite plus nitrate as $\mathrm{N}$

ammonia as $\mathrm{N}$

orthophosphate as $\mathrm{P}$

\section{Herbicides}

alachlor

ametryn

atrazine

cyanazine

metribuzin

metolachlor

prometon

prometryn

propazine

simazine

terbutryn

Herbicide Metabolites

cyanazine amide

deethylcyanazine

desethylatrazine

desisopropylatrazine

ESA colorimetric

colorimetric

colorimetric

colorimetric

SPE-GC/MS

SPE-GC/MS

SPE-GC/MS

SPE-GC/MS

SPE-GC/MS

SPE-GC/MS

SPE-GC/MS

SPE-GC/MS

SPE-GC/MS

SPE-GC/MS

SPE-GC/MS

SPE-GC/MS

SPE-GC/MS

SPE-GC/MS

SPE-GC/MS

SPE-ELISA

\section{$0.01 \mathrm{mg} / \mathrm{L}$ \\ $0.05 \mathrm{mg} / \mathrm{L}$ \\ $0.01 \mathrm{mg} / \mathrm{L}$ \\ $0.01 \mathrm{mg} / \mathrm{L}$}

$0.05 \mu \mathrm{g} / \mathrm{L}$

$0.05 \mu \mathrm{g} / \mathrm{L}$

$0.05 \mu \mathrm{g} / \mathrm{L}$

$0.05 \mu \mathrm{g} / \mathrm{L}$

$0.05 \mu \mathrm{g} / \mathrm{L}$

$0.05 \mu \mathrm{g} / \mathrm{L}$

$0.05 \mu \mathrm{g} / \mathrm{L}$

$0.05 \mu \mathrm{g} / \mathrm{L}$

$0.05 \mu \mathrm{g} / \mathrm{L}$

$0.05 \mu \mathrm{g} / \mathrm{L}$

$0.05 \mu \mathrm{g} / \mathrm{L}$

$0.05 \mu \mathrm{g} / \mathrm{L}$

$0.05 \mu \mathrm{g} / \mathrm{L}$

$0.05 \mu \mathrm{g} / \mathrm{L}$

$0.05 \mu \mathrm{g} / \mathrm{L}$

$0.1 \mu \mathrm{g} / \mathrm{L}$ 


\section{Quality Assurance}

Detailed instructions will be provided for collection and processing of samples. Analytical procedures will follow published methods. Quality-assurance samples will be used to document the precision and accuracy of analytical results. Quality-assurance samples will consist of laboratory duplicates (10 percent), blind duplicates and blanks (10 percent), and distilled water spikes (5-10 percent).

\section{DATA ANALYSIS METHODS AND REPORTS}

Because of the short-term temporal variability inherent in herbicide concentrations at an individual site and the effects of precipitation and runoff patterns, results from this study cannot be used to make statements about changes in herbicide concentrations in an individual basin. Instead the 53 sites selected for this study are assumed to be a random sample of Midwestern streams. Statistical procedures will be used to analyze the results and to statistically compare the 1994 data with data collected from these same sites in 1989 and 1990. Because the herbicide data are not expected to be normally distributed, nonparametric statistical procedures such as the Wilcoxon signed rank test for paired samples and logistic regression (Helsel and Hirsch, 1992) will be used to determine if the distributions of herbicide concentrations in 1994 are different from those reported for 1989 and 1990. These procedures will be performed for all major herbicides, nitrate, streamflow, and some physical parameters. Boxplots will be used to graphically compare results.

If atrazine use has decreased and the use of other herbicides, such as cyanazine and metolachlor has increased, the ratios of the concentrations of these herbicides to atrazine may be more sensitive to changes than the herbicides themselves. Consequently, the statistical tests described above will also be made for these ratios. The above statistical comparisons between the 1994 and 1989-90 time periods will also be attempted on a subregional scale for individual and combinations of States.

Results of the statistical analysis and results of the atrazine, cyanazine, and alachlor metabolite analyses will be interpreted and presented in one or more scientific papers. The data will be published in a USGS Open-File Report.

\section{REFERENCES}

Aga, D.S., Thurman, E.M., and Pomes, M.L., 1994, Determination of alachlor and its sulfonic acid metabolite in water by solid phase extraction and enzyme-linked immunosorbent assay: Analytical Chemistry, v. 66, p. 1495-1499.

Baker, D.B., and Richards, R.P., 1989, Herbicide concentration patterns in rivers draining intensively cultivated farmlands of northwestern Ohio, in Weigmann, D., ed., Pesticides in the Terrestrial and Aquatic Environments, Proceedings of a National Research Conference, May 11-12, 1989: Blacksburg, Va., Virginia Polytechnic Institute \& State University p. 103120.

Battaglin, W.A., Goolsby, D.A. and Coupe, R.H., 1993, Annual use and transport of agricultural chemicals in the Mississippi River, 1991-92, in Goolsby, D.A. and others, eds., Selected papers on agricultural chemicals in water resources of the Midcontinental United States: U.S. Geological Survey Open-File Report 93-418, p. 26-38. 
Fishman, M.J., and Friedman, L.C., 1989, Methods for determination of inorganic substances in water and fluvial sediments: U.S. Geological Survey Techniques of Water Resources Investigations, book 5, chap. A1, $545 \mathrm{p}$.

Frank, Richard, Braun, H.E., Holdrinet, M. Van Hove, Sirons, G.J., and Ripley, B.D., 1982, Agriculture and water quality in the Canadian Great Lakes Basin: V., Pesticide Use in 11 Agricultural Watersheds and Presence in Streamwater, 1975-1977: Journal of Environmental Quality, v. 11, p. 497-505.

Gianessi, L.P., 1992, U.S. Pesticide use trends: 1966-1989: Resources for the Future, 22 p.

Goolsby, D.A., Thurman, E.M., and Kolpin, D.W., 1991, Geographic and temporal distribution of herbicides in surface waters of the upper Midwestern United States, 1989-90, in Mallard, G.E., and Aronson, D.A., eds., U.S. Geological Survey Toxic Substances Hydrology Program-Proceedings of the technical meeting, Monterey, California, March 11-15, 1991: U.S. Geological Survey Water-Resources Investigations Report 91-4034, p. 183-188.

Goolsby, D.A., and Battaglin, W.A., 1993, Occurrence, distribution, and transport, of agricultural chemicals in surface waters of the Midwestern United States, in Goolsby, D.A., and others, eds., Selected papers on agricultural chemicals in water resources of the Midcontinental United States: U.S. Geological Survey Open-File Report 93-418, p. 1-24.

Goolsby, D.A., Battaglin, W.A., Fallon, J.D., Aga, D.S., Kolpin, D.W., and Thurman, E.M., 1993, Persistence of herbicides in selected reservoirs in the Midwestern United States--Some preliminary results, in Goolsby, D.A., and others, eds., Selected papers on agricultural chemicals in water resources of the Midcontinental United States: U.S. Geological Survey Open-File Report 93-418, p. 51-63.

Goolsby, D.A., Battaglin, W.A., and Thurman, E.M., 1993, Occurrence and transport of agricultural chemicals in the Mississippi River Basin, July through August, 1993: U.S. Geological Survey Circular 1120-C, 22 p.

Helsel, D.R., and Hirsch, R.M., 1992, Statistical methods in water resources: Amsterdam, the Netherlands, Elsevier Science Publishers, 552 p.

Leonard, R.A., 1988, Herbicides in surface waters, in Grover, R., ed., Environmental Chemistry of Herbicides, v. I: R. Grover, ed., Boca Raton, Fla., CRC Press, p. 45-87.

Lucey, K.J., and Goolsby, D.A., 1993, Effects of climatic variations over 11 years on nitratenitrogen concentrations in the Raccoon River, Iowa: Journal of Environmental Quality, v. 22, p. 38-46.

Meyer, M.T., Mills, M.S., and Thurman, E.M., 1993, Automated solid-phase extraction on herbicides from water for gas chromatography/mass spectrometry analysis: Journal of Chromatography, v. 629, p. 55-59.

Snow, D.D. and Spalding, R.F., 1988, Soluble pesticide levels in the Platte River basin of Nebraska in Agricultural Impacts on Ground Water - A Conference, Des Moines, Iowa, March 21-23, 1988, Proceedings: American Association of Ground Water Scientists and Engineers, p. 211-233. 
Thurman, E.M., Meyer, M.T., Pomes, M.L., Perry, C.E., and Schwab, A.P., 1990, Enzyme-linked immunosorbent assay compared with gas chromatography/mass spectrometry for the determination of herbicides in water: Analytical Chemistry, v. 62, p. 2043-2048.

Thurman, E.M., Goolsby, D.A., Meyer, M.T., and Kolpin, D.W., 1991, Herbicides in surface waters of the Midwestern United States--The effect of spring flush: Environmental Science and Technology, v. 25, p. 1794-1796.

Thurman, E.M., Goolsby, D.A., Meyer, M.T., Mills, M.S., Pomes, M.L., and Kolpin, D.W., 1992, A reconnaissance study of herbicides and their metabolites in surface water of the Midwestern United States using immunoassay and gas chromatography/mass spectrometry: Environmental Science and Technology, v. 26, no. 12, p. 2440-2447.

U.S. Department of Agriculture, 1990, Agricultural Chemical Usage--1990 Field Crops Summary: Washington, D.C., U.S. Department of Agriculture, National Agricultural Statistics Service, $154 \mathrm{p}$.

U.S. Department of Agriculture, 1991, Agricultural Chemical Usage--1991 Field Crops Summary: Washington, D.C., U.S. Department of Agriculture, National Agricultural Statistics Service, $150 \mathrm{p}$.

U.S. Department of Agriculture, 1992, Agricultural Chemical Usage--1992 Field Crops Summary: Washington, D.C., U.S. Department of Agriculture, National Agricultural Statistics Service, $118 \mathrm{p}$.

Wauchope, R.D., 1978, The pesticide content of surface water draining from agricultural fields A review: Journal of Environmental Quality, v. 7, p. 459-472. 